\title{
New Industrial Fields, Innovativeness and Firms' Competitive Advantage: The Birth of the Hungarian Blockchain Ecosystem
}

\author{
Viktoriia Semenova $^{1 *}$, Ph.D. student; Israa Qutishat ${ }^{2}$, MBA; and Szabolcs S. Sebrek ${ }^{3}$, Ph.D. \\ Associate Professor \\ ${ }^{1}$ Doctoral School of Business and Management, Corvinus University of Budapest, Hungary \\ ${ }^{2}$ MBA center, Corvinus University of Budapest, Hungary \\ ${ }^{3}$ Department of Business Studies and Corvinus Institute of Advanced Studies, Corvinus University of Budapest, \\ Hungary, ORCID: https://orcid.org/0000-0002-3625-1456
}

\begin{abstract}
The rapid development of information technologies spurs changes in industry structure by creating new market opportunities, business models, ventures as well as transforming the incumbent businesses. As the drivers of innovation and the first movers, startup companies seize the profit opportunities and create high value-added and cross-industrial offerings. This study is among the first to discuss the new technology adoption process on the example of blockchain technology and the subsequent formation of a concomitant ecosystem in Hungary. The paper aims to overcome the lack of empirical research studies on blockchain impact on businesses by presenting the examples of startup firms' activities and their blockchain-based solutions to the existing problems. We adopt a qualitative explorative approach and build on six case study interviews with the Hungarian blockchain-related start-ups' founders/cofounders, an expert interview and pertinent literature review. Applying the dynamic capabilities and the ecosystem framework perspective, the study contributes to analyzing the birth and development of new blockchain ecosystem and its focal offers. The research demonstrates different real-world use cases across a number of industries, the key role of innovative entrepreneurs in the ecosystem formation and collects information on the value propositions, competitive advantages, and distinctive capabilities of the blockchain ecosystem members. The managerial implications and further research directions are discussed.
\end{abstract}

Keywords: blockchain technology; ecosystem; start-ups

\section{Introduction}

Blockchain technology is one of the emerging technologies that underpin the fourth industrial revolution and has a major impact on businesses because blockchain as a foundational technology (Iansiti \& Lakhani, 2017) facilitates other technologies' convergence (artificial intelligence, machine learning, the Internet of things) and can unlock their full value. According to Deloitte's 2020 Blockchain Survey, business leaders see blockchain technology as a connecting platform enabling many business processes and thereby as integral to organizational innovation (Pawczuk et al., 2020). Initially designated for facilitating 
2nd International Conference on Applied Research in BUSINESS, MANAGEMENT and ECONOMICS
25-27 September 2020

Berlin, Germany

transactions, the technology has spread across different industries, and it is applicable to diverse businesses and organizations.

Due to the novelty of the technology, the majority of companies are start-ups within the blockchain ecosystem. The rapid growth in blockchain start-ups and the volume of their funding is observed across the USA, China, and the European Union (Nascimento et al., 2019). The global enterprise blockchain ecosystem is growing rapidly with the US leading role in blockchain start-ups funding. Meanwhile, Europe is also catching up and its early stage blockchain ecosystem is increasing with more than 500 new ventures created each year and with existing B2B start-ups deploying blockchain to add value to their product offerings (Puel et al., 2020). Contrary to large companies, start-ups are faster to adopt novel technologies as they serve as the engine of innovative activity in certain industries (Audretsch, 2002), especially in the ICT sector, and they are important sources of employment growth. Since startup firms are the ones who have innovative business models and play a dynamic role in the economy (Audretsch, 2002), the purpose of the given study is to explore the Hungarian blockchain-related start-ups, key issues of their business models and value propositions as well as competitive advantages. From the perspective of ecosystem research and dynamic capabilities (DCs) framework, the paper examines the blockchain adoption process in Hungary, the main actors, their key activities and reveals the subtleties of emergence of Hungarian blockchain ecosystem. In order to achieve this objective, the following research questions are raised: Which companies have started using the technology of blockchain in their operations and in which sectors do they work? What problems do the companies try to solve and which solutions on blockchain do they offer?

The paper is organized as follows. In the first part, the significance of blockchain technology is discussed and the phenomenon of blockchain is embedded into the ecosystem and DCs framework context. Subsequently, the empirical part of the study is developed around the interviews with blockchain start-ups. Finally, the concluding remarks are complemented by managerial implications and promising future research directions.

\section{Literature review}

\subsection{Conceptualization of blockchain technology and its significance for business}

Iansiti \& Lakhani (2017) believe that blockchain is a foundational technology that can create new foundations for economic and social systems (p. 4) and gradually reshape the economy by the replacement of traditional businesses and the emergence of new technology companies. This is exactly the same path as adopting the other foundational technologies like transmission control protocol/ internet protocol (TCP/IP), which provided the basis for the internet development (Iansiti \& Lakhani, 2017). In the framework of the Schumpeterian paradigm, blockchain is a radical disruptive innovation that has the general-purpose technology (GPT) characteristics (Pilkington, 2016; Kane, 2017). Firstly, its radicalism is identified with the high level of the transformations of the technologies, infrastructures, and markets. Secondly, the blockchain bearing the features of GPT is applicable in many fields and compatible with other technologies like AI and IoT, and technology is expected to economize production costs and improve on productive efficiency of some economic operations (Davidson et al., 2018) and thereby lead to "waves of growth" (Kane, 2017). 
2nd International Conference on Applied Research in BUSINESS, MANAGEMENT and ECONOMICS
25-27 September 2020

Berlin, Germany

Through the lens of transaction costs economics (Williamson, 1979), blockchain's primary effect is on lowering transaction costs of economic coordination and governance between a network of economic agents. According to Tapscott \& Tapscott (2016), blockchain is expected to create new portfolios of value. Angelis \& Ribeiro (2019) also believe that the associated value propositions change since blockchain technologies provide new functionalities (p. 307). Moreover, maturing technology ordinarily enables new manners of service and product offerings and includes modifications in the pursued and derived benefits (Angelis \& Ribeiro, 2019, p. 308). Blockchain, as a new paradigm for organizing activity, allows companies to reduce friction and information asymmetries (Tapscott \& Tapscott, 2016) and ensure more efficiency at a much greater scale than current paradigms (Swan, 2015, p. 27).

To date, blockchain's sophisticated ledger system is widely used by companies, startups, non-governmental organizations, and governments for multiple applications including payments, smart contracts, property rights, insurance, certification, logistics platforms, wallets, and many others (Davidson et al., 2018; Kher et al., 2020); however, blockchain research lacks empirical investigations. The outcomes of Frizzo-Barker et al. (2020) review of blockchain research in the business literature reveal that blockchain technology remains an early-stage area of research in terms of theoretical basis, methodological diversity, and empirically grounded work. Frizzo-Barker et al. (2020) call for a need to generate empirical case studies about specific blockchain solutions for new businesses. Thus, our study attempts to fill this gap and alleviate a dearth of empirical research by investigating the existing Hungarian blockchain-related start-ups and the blockchain-enabled applications.

\subsection{The embeddedness of blockchain technology into the ecosystem research}

Blockchain, as an institutional technology, requires groups to adopt (Allen et al., 2020), so due to its functionality blockchain only works at its full potential in a network to achieve cost reduction, transparency, security, and credibility. Nasdaq Vice President notes that one needs to have "a complete ecosystem on the blockchain for it to offer maximum value to all its participants" (Nasdaq, 2016). This statement is in line with the main purpose of the ecosystem that is the generation of value by all participants' mutual efforts (Adner, 2006).

According to the definition of the ecosystem, firms should be considered not as members of a single industry but rather as members of a business ecosystem consisting of different industries (Moore, 1993). Subsequently, Iansiti \& Levien (2004) describe the ecosystem as "a large number of loosely interconnected participants who depend on each other for their mutual effectiveness and survival" (p. 76). Adner's (2017) definition of ecosystem construct states that it is "the alignment structure of the multilateral set of partners that need to interact in order for a focal value proposition to materialize" (p. 42). Adner (2017) places the value proposition at the foundation of the ecosystem consisting of activities, actors, positions, links that contribute to the value creation. The ecosystem can generate opportunities and niches for firms (Iansiti \& Levien, 2004; Adner, 2006) by bringing such benefits as open innovation, value network, platform leadership, keystone strategies, hyperlinked organizations, and organizational culture interchange.

Jacobides et al. (2018) define ecosystems as distinct forms of organizing economic activities that are characterized by specific types of complementarities (p. 2256). In the context 
of the platform ecosystem, there are hub-and-spoke networks where a set of peripheral firms link to the central platform through open-source technologies and technical standards (Jacobides et al., 2018, pp. 2256-2257). A platform leader is responsible for managing the technological evolution of the system to maintain competitiveness against rival ecosystems (Kay et al., 2018, p. 633). Regarding blockchain, there are many open-source platforms like Ethereum, Hyperledger, Corda, Ripple, and others developed by technology companies for faster and easier business application development.

A multiplicity of platforms indicates that there is no dominant design in the blockchain industry and homogeneity among the ventures. Meanwhile, Frolov (2019) points out that a multilevel environment with a continuous self-development potential will be established on the blockchain basis. Therefore, blockchain with its ability to generate different complements is forming the ecosystem for platform leaders and developers where ecosystem stakeholders can form competitive and cooperative relationships with blockchain platform leaders $(\mathrm{Ku}$, 2020, p. 305). Blockchain as decentralized network technology relies on the network effect for its proliferation and growth $(\mathrm{Ku}, 2020)$. Thus, Jacobides et al. (2018) emphasize the importance of ecosystem formation for emerging areas and the necessity to study the dynamics in nascent sectors and understand the approaches enabling the ecosystem identification. Kapoor (2018) suggests that the ecosystem research can be conducted at the level of the focal offer (innovation and technology). Insofar as new technology can trigger the formation of the ecosystem, this study explores the main activities that constitute different offers and the actors undertaking these activities and producing those offers.

\subsection{Dynamic capabilities perspective for studying the ecosystem formation}

Like any form of organizations, the business ecosystem also undergoes changes with time, and the success of the ecosystem performance depends on its co-evolvement with technologies and the market (Heaton et al., 2019). Hence, the dynamic capabilities theory can be the appropriate paradigm to explore sensing of business opportunities from the environment and understand technology management (Cetindamar et al., 2009) as the effective management of technology can facilitate the conversion of the opportunities into value. Moreover, there is a positive interrelation between the DC, operational capabilities, and firm performance (Wilden \& Gudergan, 2015). Insofar as technologies are identified as DCs (Franco et al., 2009; Kosztyán et al., 2018), blockchain positively impacts the performance of economic actors.

According to Teece (2014), strong DCs and strategy are the basis for the sustained competitive advantage. Enterprises with such capabilities are capable to adapt to business ecosystems and shape them through innovation and cooperation with other enterprises and entities (Teece, 2007, p. 1319). Those strong capabilities include entrepreneurial ability to discover emerging areas, invest in research around them, and build partnerships for creating and maintaining ecosystem infrastructure (Heaton et al., 2019). Kay et al. (2018) note that the main benefits of participating in ecosystems are access to proprietary knowledge, participation in setting common standards, and coordination of capabilities development. Thus, blockchain technology creates vast opportunities to conduct research on the formation of the blockchain innovation ecosystem globally or in a given country. The DC framework can be applied to analyze how various participants adapt to the current technological changes and contribute to blockchain ecosystem formation. 
2nd International Conference on Applied Research in BUSINESS, MANAGEMENT and ECONOMICS
25-27 September 2020

Berlin, Germany

\section{Methodology}

\subsection{Case study research}

This research has adopted a qualitative, explorative approach. Given the exploratory nature of this study, this empirical research is based on multiple case studies (Yin, 2003) that aims at providing a description of the actors in forming the blockchain ecosystem. There are three main goals that case studies may accomplish including the exploration, testing, or building theory (Eisenhardt, 1989, p. 535). According to the definition by Yin (2003), a case study "investigates a contemporary phenomenon within its real-life context"; therefore, it is an appropriate research approach to examine a process of the new technology adoption. Moreover, Kouhizadeh et al. (2019) noted that the case studies on blockchain applications have been widely used in recent papers and they are considered a suitable approach to systematically and theoretically analyze industry experience and develop the research design and theories or models. In order to gain in-depth insights into the uptake of the emerging blockchain technology in Hungary and the value this technology brings for organizations, the authors of this paper have chosen to engage with the innovative entrepreneurs which are developing blockchain-based solutions to the existing problems.

\subsection{Data collection}

The study employs multiple methods of data collection. Qualitative data gathering and analysis have been proceeded simultaneously. Due to the nature of the study, the startup companies in their early and mature development stages are examined. The main sources of data about these companies are collected from their official websites, online news, and the semi-structured interviews conducted with start-ups management (see Table 1).

According to Giarratana (2004), it is important to assess the firm founders' characteristics, their incentives and capabilities they brought inside the company and how they shaped the firm in the initial stages (p. 796). Regarding the backgrounds of our interviewees, two informants (the CEOs of bedrock.farm and Meddictive) were former founders of the other start-ups, the CEOs of WarrantIQ and InsurWiz were former government servants, and four founders out of six were employees or managers of large companies. For instance, the CEO of Meddictive has multi-industrial managerial working experience in developing business in the CEE markets and Germany, and he is currently lecturing at Semmelweis and Edutus Universities. In general, most start-ups are established by entrepreneurs who were previously employed in the same industry and left their current employment in order to take advantage of a recognized opportunity.

Table 1: Interviews with start-ups founders

\begin{tabular}{|c|c|c|c|}
\hline Interviewee & Position & Company & Website \\
\hline Szücs Endre & Managing director & bedrock.farm & $\underline{\text { http://bedrock.farm/ }}$ \\
\hline Jogg Dániel & CEO & Enerhash & $\underline{\text { https://www.enerhash.com/ }}$ \\
\hline Urbán Viktor & CEO & InsurWiz Technology & $\underline{\text { https://insurwiz.io/ }}$ \\
\hline Czeglédi Tamás & CEO & Meddictive & $\underline{\text { https://meddictive.com/ }}$ \\
\hline
\end{tabular}


2nd International Conference on Applied Research in BUSINESS, MANAGEMENT and ECONOMICS
25-27 September 2020

Berlin, Germany

\begin{tabular}{|c|c|c|c|} 
Brezovszki Máté & CEO & Solidity Services & $\underline{\text { https://solidity.services/ }}$ \\
\hline Kalocsai Kornél & CEO & WarrantIQ & $\underline{\text { https://www.warrantiq.com/ }}$ \\
\hline
\end{tabular}

In order to select the potential Hungarian companies for interviews, the materials about these companies were collected from publicly available sources: websites of the Blockchain Hungary Association (BHA, 2020) and the B-Day 3.0 conference (Blockchain Budapest, 2020) which is one of the CEE's largest blockchain events organized since 2018. Our sample consists of 6 case studies derived from agricultural, energy, insurance, health, finance, and warranty industries. This number is enough for providing an accurate account in empirical research when its purpose is mainly explorative. According to Eisenhardt (1989), 4-10 cases are considered a sufficient amount (p. 545). These cases have been selected because they provide a representative sample of different types of companies. Also, an expert interview was conducted with a professor teaching a blockchain course at the Budapest University of Technology and Economics (BME) to better understand the technical terminology.

From April to July 2020, the interviews were conducted by at least three members of the research group. The questions for interviews were aggregated into three main groups, corresponding to the major sections of the interview protocol including the background of the interviewee, key activities of the company, and the blockchain application in its processes. In data analysis, we tried to triangulate observed data by combining the material from the interviews, both firms' and different organizations' official websites.

\section{Findings}

\subsection{Case firms and their success factors}

In Table 2, we present an overview of our selected firms, emphasizing their names, location, business innovation, services and products based on blockchain solutions, signals of success and distinctive capabilities. The common point among these companies is the fact that most of them are the first movers in the Hungarian market that have started implementing blockchain to solve different kinds of existing problems and streamline some operations. Meanwhile, among these companies, there are some players who went out of business (e.g., WarrantIQ) due to personal circumstances, and there are some companies that decided to replace one blockchain platform to another one (e.g., Meddictive). All these cases demonstrate how these companies utilize and test the emerging technology. 
2nd International Conference on Applied Research in BUSINESS, MANAGEMENT and ECONOMICS
25-27 September 2020

Berlin, Germany

Table 2: Examined Companies Overview*

\begin{tabular}{|c|c|c|}
\hline $\begin{array}{l}\text { Company / } \\
\text { Location }\end{array}$ & $\begin{array}{l}\text { Business Innovation/ } \\
\text { Services/Products }\end{array}$ & $\begin{array}{l}\text { Signals of success \& } \\
\text { distinctive capabilities }\end{array}$ \\
\hline $\begin{array}{l}\text { Meddictive Ltd. } \\
\text { - Hungary } \\
\text { - Bulgaria }\end{array}$ & $\begin{array}{l}\text { - Blockchain-based tissue tracking and } \\
\text { trading platform for healthcare } \\
\text { professionals } \\
\text { - Consultancy services on many } \\
\text { complementary technologies, mainly, } \\
\text { medical equipment } \\
\text { - Teaching specialized courses at the } \\
\text { medical universities }\end{array}$ & $\begin{array}{l}\text { - First mover in the Hungarian market } \\
\text { - Cooperation with } 5 \text { universities } \\
\text { - Development of mobile application with QR code and } \\
\text { crypto wallet } \\
\text { - Tissue banking platform operating as a marketplace to } \\
\text { connect tissue banks, universities, and hospitals } \\
\text { - Participation in the blockchain development unofficial } \\
\text { consulting board for the government and the tissue } \\
\text { restructuring consulting board }\end{array}$ \\
\hline $\begin{aligned} & \text { Enerhash } \\
& \text { - Hungary } \\
& \text { - Slovakia } \\
& \text { - Russia } \\
& \text { - Hong Kong }\end{aligned}$ & $\begin{array}{l}\text { - Selling databox (containers) to power } \\
\text { plants; building the data centers and } \\
\text { renting out the places inside it } \\
\text { - Selling computers / servers to } \\
\text { companies and individuals }\end{array}$ & $\begin{array}{l}\text { - First mover in the Hungarian market } \\
\text { - Diverse set of partners ranging from small to large power } \\
\text { plants and other various unnamed clients } \\
\text { - Decentralized data centers and special software } \\
\text { - Cryptocurrency mining } \\
\text { - Use of cryptocurrencies for international payments }\end{array}$ \\
\hline $\begin{array}{l}\text { bedrock.farm } \\
\text { - Hungary }\end{array}$ & $\begin{array}{l}\text { - Production of microgreens, herbs, } \\
\text { leafy greens with the exploitation of } \\
\text { indoor and control environmental } \\
\text { technologies } \\
\text { - Selling the information about how to } \\
\text { grow plants and the recipes to } \\
\text { greenhouses and all other customers } \\
\text { - Creating a platform where everybody } \\
\text { can build their own businesses }\end{array}$ & $\begin{array}{l}\text { - Production of local and high-quality food year-round } \\
\text { - No fluctuation in price and quality } \\
\text { - Blockchain application for the purpose of certification and } \\
\text { validation } \\
\text { - Willingness to be more transparent than other agricultural } \\
\text { companies and thereby build trust with its clients } \\
\text { - Closeness to their customers } \\
\text { - Intention of creating a decentralized network for food } \\
\text { production in the future }\end{array}$ \\
\hline $\begin{array}{l}\text { WarrantIQ } \\
\text { - Hungary }\end{array}$ & $\begin{array}{l}\text { - Managing warranties } \\
\text { - Issuance of online warranty } \\
\text { - Saving and earning money }\end{array}$ & $\begin{array}{l}\text { - Blockchain-based solution to manage and trace warranty } \\
\text { documents } \\
\text { - Make warranty data accessible for subsequent services } \\
\text { - Simplification of the warranty process } \\
\text { - Diverse clients from the B2C to B2B markets } \\
\text { - Strong management background of the founders }\end{array}$ \\
\hline $\begin{array}{l}\text { InsurWiz } \\
\text { Technology } \\
\text { - Hungary }\end{array}$ & $\begin{array}{l}\text { - Digital insurance } \\
\text { - Blockchain-based weather insurance }\end{array}$ & $\begin{array}{l}\text { - One of the first tangible blockchain-based solutions } \\
\text { - Partnership with AEGON } \\
\text { - Interest from other insurance providers }\end{array}$ \\
\hline
\end{tabular}




\begin{tabular}{|c|c|c|}
\hline $\begin{array}{l}\text { Solidity Services } \\
\text { (franchise system) } \\
\text { - Hungary } \\
\text { - Denmark } \\
\text { - the UK } \\
\text { Subsidiaries: } \\
\text { Galaxis Network } \\
\text { - Hungary } \\
\text { Inventori } \\
\text { platform } \\
\text { - Hungary }\end{array}$ & $\begin{array}{l}\text { - Consulting (pre-sales activity) } \\
\text { - Provide blockchain and business } \\
\text { training courses } \\
\text { - Software development services } \\
\text { (building blockchain-based web } \\
\text { applications with new functionality) } \\
\text { - A blockchain-based digital asset } \\
\text { management platform powered by } \\
\text { smart contracts on Ethereum } \\
\text { - A blockchain-based product tracking } \\
\text { and chain of custody solution }\end{array}$ & $\begin{array}{l}\text { - First mover in the Hungarian market } \\
\text { - Agency business model, creation of a strong brand } \\
\text { - International strategy, outsourcing tasks from the Western } \\
\text { market } \\
\text { - A high-skilled team } \\
\text { - Diverse interrelated set of partners / subsidiaries in } \\
\text { Denmark and the UK besides the Hungarian branches } \\
\text { - A variety of clients ranging from banks to legal offices and } \\
\text { start-ups } \\
\text { - Pioneering platforms applying blockchain and smart } \\
\text { contracts } \\
\text { - A set of services covering technical and business sides }\end{array}$ \\
\hline
\end{tabular}

*Table is created by authors based on the interviews and companies' websites

\subsection{Problems and blockchain-related innovative solutions}

In this section, we intend to reveal the different business problems for which our sampled firms aim to offer their innovative solutions as well as to identify the companies' roles in the discussed ecosystem. In the context of firms' function, the interviewed companies perform as the complementors to the focal offerings and the open-source platforms. Note that due to space limitation, we only consider fewer firms than shown in Table 2. The other problems (P) and innovative solutions (IS) are available from the authors.

$\underline{P 1}$ : Providing professional educational and consultancy services to various stakeholders.

IS 1: Consultancy, offering services on software development and training course packages on public blockchain programming and consortium technologies.

Solidity Services is a Europe-based professional blockchain services network that has started its operations in 2018. It provides assistance in technology implementation and supports global adaptation across different industries by using the existing blockchain networks and building specific use cases and business applications upon them with additional functionality. With its services and products, Solidity Services serves as a complementor to offerings of its clients among them banks and financial institutions, legal offices, logistics and supply chain traceability organizations, start-ups, and real estate agencies. For instance, the company provides a particular blockchain-based solution for bedrock.farm. The example of Solidity Services demonstrates the high degree of interconnectedness between ecosystem members: except for creating a loyal customer base, the founders have built partnerships with the Western companies by establishing a franchise system. As a result, Solidity Services manages several spin-offs including Galaxis Network, the Inventori platform (Hungary), Defactory.io (Denmark).

$\underline{P 2}$ : Identification, traceability, and registration of transactions in a digital manner.

IS2: Addressing problems related to transparency, trust, immutability in various industries.

Meddictive Ltd. is the first Hungarian business entity with tissue bank registration. It is also a registered tissue bank in Bulgaria and other three countries already under registration. At this time, this startup company is at a mature development phase while it was set up in 2017 due to sensing activities of Blockchaineum consultancy agency that identified blockchain potential in the health sector. The objective of the company is to improve the cross-border 
2nd International Conference on Applied Research in BUSINESS, MANAGEMENT and ECONOMICS
25-27 September 2020

Berlin, Germany

tissue flow within the member states of the European Union by involving all the interested actors of the tissue market to increase the available supply and quality as well as to make scientific and clinical data accessible. To achieve this goal, the company operates as a marketplace through its tissue banking platform to link tissue banks, medical institutions, and universities. The company utilizes the distributed ledger to check the authenticity of the IDs and to register and track transactions of tissues. The technology of blockchain helps address the issues of transparency, trust, and immutability in the tissue industry. Table 2 outlines the Meddictive's services including the provision of consultancy services on the fitting product and the cutting-edge technologies. Meddictive involves its clients into an open innovation and R\&D process through its activity as the external source of innovation and its partnerships with the leading universities such as the Academic Centre for Dentistry Amsterdam, Manchester, Plovdiv, and Semmelweis Universities.

The Inventori platform is the Hungarian spin-off company of Solidity Services Group. The aim of the platform is to build a transparent and easy to access supply chain traceability platform to optimize the process of inventory management certificate registry and product origin validation that is operating across countries. The Inventori platform is built on decentralized distributed ledger technology: public smart contracts verify and govern the flow of assets and related information. This platform unites different participants that can digitally track the goods on the same infrastructure network with the unlimited number of stakeholders, the tamper-proof blockchain infrastructure and cryptographic principles reduce the fraud attempts and protect confidential business information while the open-source network provides free access to origin validation for the public.

bedrock.farm is a startup that works in the urban agriculture industry. They exploit blockchain technology to certify and validate data about the production, harvestation, and delivery of the produce for the purpose of being more transparent than other agricultural firms. The mission of the company is to decentralize food production by considering trust as the main value of bedrock.farm. By sharing sensitive and inner information, such as the know-how with greenhouses and other farmers and by building a platform, bedrock.farm is helping other companies to start their businesses. In this sense, the main mission of bedrock.farm is to serve as the external source of knowledge for other actors and at the same time it benefits from the cooperation with the technology providers (e.g. Solidity Services and its Inventori platform). bedrock.farm actively engages in both closed and open innovation activities.

$\underline{P 3}$ : Building, testing, and operating applications with a blockchain backend.

IS3: Developing distributed applications and smart contracts.

Meddictive Ltd. is developing a mobile application with $\mathrm{QR}$ code and crypto wallet to track time and all the movements and the changes of the tissues and manage the payments and everything through the system and thereby decrease administrative burden of the dental and medical professionals.

Solidity Services develops software and builds blockchain-based web applications, mainly on Ethereum that is the open-source and decentralized software platform; therefore, the company complements the platform providers. Based on specific requirements Solidity Services develops smart contracts covering the architecture development, the front-end interface, and the contract deployment. 
2nd International Conference on Applied Research in BUSINESS, MANAGEMENT and ECONOMICS
25-27 September 2020

Berlin, Germany

WarrantIQ was an early-stage startup initiation that operated from 2018 and was closed in March 2020 due to the personal circumstances. They were developing new e-warranty solutions for users and enterprises that were required to provide outdated paper-based warranty services. The main function of this start-up was to store and secure warranty documents on blockchain where participants such as consumers, retailers, carriers, banks, and insurance providers were involved. Such services as managing warranties and issuance of automatic online guarantee vouchers for SMEs through a warranty voucher platform saved users time and money. WarrantIQ complemented the existing blockchain-based platforms and also connected multiple stakeholders on its designed platform.

$\underline{P 4}$ : Volatility of power generation and the need for power plants to optimize their production under difficult market conditions and high system usage fees.

IS4: Providing significant added value for energy producers in terms of profitability and efficiency by doing Bitcoin mining and hosting cryptocurrency mining companies.

Enerhash offers a new solution for energy companies to maximize the value of energy production via implementing the decentralized data centers to use power plant excessive capacity for Bitcoin mining and other similar blockchain technologies. The company connects different stakeholders: it sells the Enerhash databox to power plants and builds the data centers and rents out the places inside it for the ASIC (application-specific integrated circuit) miners. So, the company provides hosting services for miners by operating their assets on low energy prices and cost-effective operations. As Enerhash is involved in global operations, the company also uses the cryptocurrencies to make payments quickly and avoid high overseas transaction fees.

\section{Discussion and conclusion}

The formation of the Hungarian blockchain ecosystem started to emerge in the end of 2016 and the beginning of 2017 amid the ICO bubble and the sharp rise in cryptocurrencies prices. The interviewed founders and other ecosystem participants identified the economy's needs and the potential of blockchain for creating new business solutions. At the initial stage of ecosystem development, there were few firms with limited identity and rare interactions between the ecosystem members. Over time, the actors have begun to cooperate around blockchain technology, exchange their knowledge and realize common opportunities via their linkages. For instance, having the expertise in banking industry, Máté Brezovszki came up with the idea of Galaxis Network. Before setting up the company, he created Solidity Services where his team provides educational services and consulting. Similarly, the CEO of Meddictive first started the Blockchaineum consulting agency and later they began to search for the possibility to apply blockchain in the tissue industry and build linkages between universities, hospitals, and different medical professionals. The example of Meddictive and Solidity Services illustrate their sensing and shaping capabilities prior to commercializing their ideas.

After sensing the opportunities, the companies have created new products, services, and processes. Today, the foundation is laid down and the ecosystem sees the increase in the number of start-ups and larger companies working with blockchain, strengthening of communication channels among the players. Companies tend to follow niche strategies (Iansiti and Levien, 2004) by developing specialized capabilities that differentiate them from other firms in the network and improving its narrow domain of expertise. The different blockchain 
2nd International Conference on Applied Research in BUSINESS, MANAGEMENT and ECONOMICS
25-27 September 2020

Berlin, Germany

stakeholders have undertaken more deliberate efforts for supporting and extending the local ecosystem's assets. For example, start-ups propose new value propositions in the market, universities such as the BME, Corvinus and Edutus Universities offer courses on blockchain, and annual blockchain conferences (e.g., Blockchain Budapest) are held.

The focus in the ecosystem study should be not exclusively on firms but additionally on the role of not-for-profit actors including individuals (Bogers et al., 2019). In this context, a significant contribution to shaping Hungarian blockchain ecosystem has already been made by the BHA led by President Kalocsai. The association tries to stimulate the information flow among the Hungarian and international participants. It facilitates knowledge transfer from the US and other countries and helps sell the Hungarian knowledge abroad. It helps bring about an alignment of interest among stakeholders as the Hungarian blockchain landscape developed by this association illustrates that there are around hundred participants and entities in the ecosystem that are trusted and well-known, and this landscape allows actors to know about other members operating in the same environment. The BHA aims at educating diverse stakeholders about the technology applications and building the legal foundations for successful functioning of blockchain ecosystem members.

To sum up, the results of the findings reveal that Hungary currently possesses the necessary characteristics of the successful ecosystem (Heaton et al., 2019). It has a sufficient amount of companies, entrepreneurs, talent, and investment. Mr. Kalocsai acknowledges that the blockchain ecosystem in Hungary is in a good condition and there are successful projects and startup firms. The start-ups contribute to realization of the European agenda on accelerating blockchain innovation and developing the ecosystem within the EU. So, the Galaxis Network participation in the EU Horizon 2020 and the Block.IS acceleration program shows the significance of its offering for the European economy.

Following the study of Enkela and Sagmeister (2020), we advise established companies to cooperate with blockchain start-ups in order to boost DCs by utilizing their expertise in the fast-evolving blockchain and related distributed ledger technologies. Policymakers must further sophisticate the legal regulation to strengthen the field which belongs to the high valueadded ICT services branch of diversified economies with the option to shield it in downturns. Future research can construct a European sample of blockchain firms (including over 100 Hungarian players) to study survival patterns in terms of covered niches, VRIN and DCs, technology management, open innovation, and proprietary technologies.

\section{Acknowledgments}

We thank all the interviewed participants. Financial support from the EFOP-3.6.3.VEKOP-16-2017-00007 "Young Researchers from Talented Students" project of the Corvinus University of Budapest is gratefully acknowledged.

\section{References}

[1] Adner, R. (2006). Match Your Innovation Strategy to Your Innovation Ecosystem. Harvard Business Review, vol. 84 (4), pp. 98-107.

[2] Adner, R. (2017). Ecosystem as Structure: An Actionable Construct for Strategy. Journal of Management, vol. 43 (1), pp. 39-58. 
[3] Allen, D. W. E., Berg, C., Markey-Towler, B., Novak, M. and Potts, J. (2020). Blockchain and the Evolution of Institutional Technologies: Implications for Innovation Policy. Research Policy, vol. 49 (1).

[4] Angelis, J. and Ribeiro da Silva, E. (2019). Blockchain Adoption: A Value Driver Perspective. Business Horizons, vol. 62 (3), pp. 307-314.

[5] Audretsch, D. (2002). The Dynamic Role of Small Firms: Evidence from the U.S. Small Business Economics, vol. 18 (1-3), pp. 13-40.

[6] Blockchain Budapest. (February 2020). The B-Day 3.0 Conference. Available: https://blockchainbudapest.com/

[7] BHA (Blockchain Hungary Association) (February 2020). About us. Available: https://www.blockchainhungary.org/blockchainhungary?lang=en

[8] Cetindamar, D., Phaal, R. and Probert, D. (2009). Understanding Technology Management as a Dynamic Capability: A Framework for Technology Management Activities. Technovation, vol. 29 (4), pp. 237-246.

[9] Davidson, S., De Filippi, P. and Potts, J. (2018). Blockchains and the Economic Institutions of Capitalism. Journal of Institutional Economics, vol. 14 (4), pp. 639-658.

[10] Eisenhardt, K.M. (1989). Building Theories from Case Study Research. Academy of Management Review, vol. 14 (4), pp. 532-550.

[11] Enkela, E. and Sagmeister, V. (2020). External Corporate Venturing Modes as New Way to Develop Dynamic Capabilities. Technovation, pp. 96-97.

[12] Franco, A. M., Sarkar, M. B., Agarwal, R. and Echambadi, R. (2009). Swift and Smart: The Moderating Effects of Technological Capabilities on the Market Pioneering-Firm Survival Relationship. Management Science, vol. 55 (11), pp. 1842-1860.

[13] Frizzo-Barker, J., Chow-White, P. A., Adams, P. R., Mentanko, J., Ha, D. and Green, S. (2020). Blockchain as a Disruptive Technology for Business: A Systematic Review. International Journal of Information Management, vol. 51.

[14] Frolov, D. (2019). Blockchain and the Institutional Complexity: Post-Institutionalism vs. Neoinstitutionalism. MPRA Paper 95962, University Library of Munich, Germany.

[15] Giarratana, M. S. (2004). The Birth of a New Industry: Entry by Start-ups and the Drivers of Firm Growth: The Case of Encryption Software. Research Policy, vol. 33 (5), pp. 787-806. [16] Heaton, S., Siegel, D. S. and Teece, D. J. (2019). Universities and Innovation Ecosystems: A Dynamic Capabilities Perspective. Industrial and Corporate Change, vol. 28 (4), pp. 921939.

[17] Iansiti, M. and Lakhani, K. R. (2017). The Truth about Blockchain. Harvard Business Review, vol. 95 (1), pp. 118-127.

[18] Iansiti, M. and Levien, R. (2004). Strategy as Ecology. Harvard Business Review, vol. 82 (3), pp. 68-78.

[19] Jacobides, M. G., Cennamo, C. and Gawer, A. (2018). Towards a Theory of Ecosystems. Strategic Management Journal, vol. 39 (8), pp. 2255-2276.

[20] Kane, E. (2017). Is Blockchain a General-Purpose Technology? Available: http://dx.doi.org/10.2139/ssrn.2932585

[21] Kapoor, R. (2018). Ecosystems: Broadening the Locus of Value Creation. Journal of Organization Design, vol. 7 (1). 
2nd International Conference on Applied Research in BUSINESS, MANAGEMENT and ECONOMICS
25-27 September 2020

Berlin, Germany

[22] Kay, N. M., Leih, S. and Teece, D. J. (2018). The Role of Emergence in Dynamic Capabilities: A Restatement of the Framework and some Possibilities for Future Research. Industrial and Corporate Change, vol. 27 (4), pp. 623-638.

[23] Kher, R., Terjesen, S. and Liu, C. (2019). Blockchain, Bitcoin, and ICOs: A Review and Research Agenda, Small Business Economics.

[24] Kosztyán, Z. T., Sebrek, S. S. and Novák, Z. (2018). A szoftverfejlesztési folyamat átfogó észszerüsítése a vállalati dinamikus képességek lencséjén keresztuil. Vezetéstudomány Budapest Management Review, vol. 49 (4), pp. $44-57$.

[25] Kouhizadeh, M., Zhu, Q. and Sarkis, J. (2019). Blockchain and the Circular Economy: Potential Tensions and Critical Reflections from Practice, Production Planning \& Control, vol. 31 (11-12), pp. 950-966.

[26] Ku, S. W. (2020). Platform Strategy for Business Transformation in a Blockchain Ecosystem. In U. Hacioglu (ed). Digital Business Strategies in Blockchain Ecosystems. Cham: Springer Nature Switzerland AG, pp. 305-316.

[27] Moore, J. F. (1993). Predators and Prey: A New Ecology of Competition. Harvard Business Review, vol. 71 (3), pp. 75-86.

[28] Nascimento S. (ed), Pólvora A. (ed), Anderberg A., Andonova E., Bellia M., Calès L., Inamorato dos Santos A., Kounelis I., Nai Fovino I., Petracco Giudici M., Papanagiotou E., Sobolewski M., Rossetti F., \& Spirito L. (April 2019). Blockchain Now and Tomorrow: Assessing Multidimensional Impacts of Distributed Ledger Technologies. EUR 29813 EN, Publications Office of the EU, Luxembourg. Available: http://dx.doi.org/10.2760/901029

[29] Nasdaq. (June 2016). Building on the Blockchain - Nasdaq's Vision of Innovation. Available: http://business.nasdaq.com/Docs/Blockchain\%20Report\%20March\%202016_tcm 5044-26461.pdf

[30] Pawczuk, L., Holdowsky, J., Massey, R. and Hansen, R. (August 2020). Deloitte's 2020 Global Blockchain Survey. From Promise to Reality. Deloitte Insights.

[31] Pilkington, M. (2016). Blockchain Technology: Principles and Applications. Research Handbook on Digital Transformations. In F. Olleros, M. Zhegu (eds.). - Cheltenham: Edward Elgar, pp. 225-253.

[32] Puel, J.M., Chreng-Messembourg, D. and Cota, B. (August 2020). Enterprise Blockchain 2020. Data Driven Insights into the Uncharted Enterprise Blockchain World \& Data Economy. LeadBlockPartners. Available: http://leadblockpartners.com/docs/Enterprise\%20Blockchain $\% 202020 \% 20 \% 20$ LeadBlock\%20Partners.pdf

[33] Swan, M. (2015). Blockchain: Blueprint for a New Economy. O’Reilly Media.

[34] Tapscott, D. and Tapscott, A. (2016). Blockchain Revolution: How the Technology behind Bitcoin is Changing Money, Business, and the World. New York, NY: Penguin.

[35] Teece, D. J. (2007). Explicating Dynamic Capabilities: The Nature and Microfoundations of (Sustainable) Enterprise Performance. Strategic Management Journal, vol. 28 (13), pp. 1319-1350.

[36] Teece, D. J. (2014). A Dynamic Capabilities-Based Entrepreneurial Theory of the Multinational Enterprise. Journal of International Business Studies, vol. 45 (1), pp. 8-37.

[37] Wilden, R. and Gudergan, S. P. (2015). The Impact of Dynamic Capabilities on Operational Marketing and Technological Capabilities: Investigating the Role of 
Environmental Turbulence. Journal of the Academy of Marketing Science, vol. 43 (2), pp. 181199.

[38] Williamson, O. (1979). Transaction Cost Economics: The Governance of Contractual Relations. Journal of Law and Economics, vol. 22 (2), pp. 233-261.

[39] Yin, R. K. (2003). Case Study Research - Design and Methods (3rd ed.), Sage, Thousand Oaks. 